\title{
Erratum to: Two types of muscarinic acetylcholine receptors in Drosophila and other arthropods
}

Caitlin Collin · Frank Hauser · Ernesto Gonzalez de Valdivia $\cdot$ Shizhong Li $\cdot$ Julia Reisenberger $\cdot$ Eva M. M. Carlsen · Zaid Khan · Niels Ø. Hansen • Florian Puhm • Leif Søndergaard • Justyna Niemiec $\cdot$ Magdalena Heninger · Guilin R. Ren · Cornelis J. P. Grimmelikhuijzen

Published online: 13 September 2013

(C) Springer Basel 2013

Erratum to: Cell Mol Life Sci (2013) 70:3231-3242

DOI 10.1007/s00018-013-1334-0

Unfortunately, the given name and family name of one of the co-author Dr. Ernesto Gonzalez de Valdivia was incorrectly published in the original publication. The correct given name and family name should read as 'Ernesto' and 'Gonzalez de Valdivia', respectively.

The online version of the original article can be found under doi:10.1007/s00018-013-1334-0.

C. Collin · F. Hauser · E. Gonzalez de Valdivia $\cdot$ S. Li ·

J. Reisenberger · E. M. M. Carlsen · Z. Khan · N. Ø. Hansen ·

F. Puhm · L. Søndergaard · J. Niemiec · M. Heninger · G. R. Ren ·

C. J. P. Grimmelikhuijzen $(\varangle)$

Center for Functional and Comparative Insect Genomics,

Department of Biology, University of Copenhagen,

Universitetsparken 15, 2100 Copenhagen, Denmark

e-mail: cgrimmelikhuijzen@bio.ku.dk 